\title{
PHOSPHATE FERTILIZATION EFFICIENCY IN SOYBEAN CULTIVARS INDICATED FOR CERRADO TROPICAL SOIL REGIONS
}

\author{
Felipe Ferreira da Silva ${ }^{1 *}$,DeurimarHerênio Gonçalves Júnior ${ }^{2}$, Gisellya da Silva Cruz ${ }^{3}$, Wallysson \\ Nascimento Lima ${ }^{4}$, Roldão Carlos Andrade Lima ${ }^{5}$, Mickaelle Alves de Sousa Lima \\ 'Universidade Estadual da Região Tocantina do Maranhão,R. Godofredo Viana, 1300 - Centro.CEP. 65901 - 480, Imperatriz - MA \\ 2Universidade Estadual do Norte Fluminense Darcy Ribeiro, Av. Alberto Lamego, 2000 - Parque Califórnia, Campos dos Goytacazes - \\ RJ CEP: 28013-602 \\ ${ }^{3}$ Universidade Federal Rural do Semi Árido (UFERSA), Av. Francisco Mota, 572 - Bairro Costa e Silva, Mossoró/RN - CEP: 59.625-900 \\ ${ }^{4}$ Universidade Federal do Ceará Av. da Universidade, 2853 - Benfica, Fortaleza - CE, CEP 60020-181 \\ ${ }^{5}$ Universidade Federal do Espírito Santo, Alto Universitário, s/nº - Guararema, Alegre - ES | CEP 29500-000
}

*Autor para correspondência: Felipe Ferreira da Silva, fsfelipe21@gmail.com

\begin{abstract}
Phosphorus deficiency $\left(\mathrm{P}_{2} \mathrm{O}_{5}\right)$ is among the main abiotic stresses that limit soybean production in cerrado soils. Its low availability in soils, especially in the more weathered and acidic ones, the increased demand and its scarcity estimations leadto the need for the development of cultivars more efficient in the use of this mineral. This experiment was conducted under field conditions in the municipality of Imperatriz, state of Maranhão, Brazil, under planosol conditions, in a randomized complete block design, with treatments arranged in a $2 \times 4$ factorial scheme with four replicates, four $P$ levels $\left(0,60,120\right.$ and $\left.180 \mathrm{~kg} \mathrm{ha}^{-1}\right)$, and two soy bean cultivars (BRS $333 \mathrm{RR}$ and BRS 9180 IPRO) indicated for tropical regions or Brazilian cerrado. In this study, $\mathrm{P}_{2} \mathrm{O}_{5}$ efficiency use was evaluated based on plant height, shoot dry mass (SDM), pod dry mass (PDM) and number of pods (NP). BRS 333 RR cultivar obtained the highest efficiency with doses of $84.35 \mathrm{~kg} \mathrm{ha}^{-1}$ and $94.46 \mathrm{~kg} . \mathrm{ha}^{-1}$, producing $696,76.76 \mathrm{~g} \mathrm{e} 86,72.06 \mathrm{~g}$ for SDM and PDM respectively, average height of94.15 cm with $123.98 \mathrm{kh} \cdot$ ha $^{-1}$ and phosphate fertilizer use efficiency (FUE) of $13 \%$.
\end{abstract}

KEYWORDS: ecotone,P fixation, Glycine max, weathering.

\section{EFICIÊNCIA DA ADUBAÇÃO FOSFATADA EM CULTIVARES DE SOJA INDICADAS PARA REGIÕES DE SOLOS TROPICAIS DE CERRADO}

RESUMO: A deficiência de fósforo $\left(\mathrm{P}_{2} \mathrm{O}_{5}\right)$ está entre os principais estresse sabióticos que limita a produtividade da soja em solos de cerrado. Sua baixa disponibilidade nos solos, principalmente nos mais intemperizados e ácidos, o aumento da demanda e das estimativas de sua escassez, inferem na necessidade de desenvolvimento de cultivares mais eficientes na utilização desse mineral. 0 experimento foi conduzido em condições de campo, na cidade de Imperatriz - MA, Brasil, sob condições de Planos solo, em delineamento blocos casualizados, fatorial

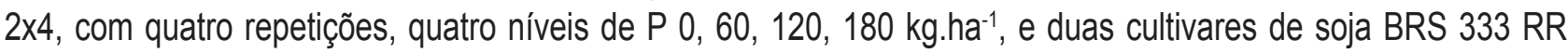
e BRS 9180 IPRO indicadas para regiões de zona tropical ou cerrado brasileiro. Neste estudo, avaliou-se a eficiência do uso de $\mathrm{P}_{2} \mathrm{O}_{5}$ com base na altura de plantas, produção de massa seca da parte aérea (MSPA), massa seca de vagens (MSV) e número de vagens. A cultivar BRS 333 RR obteve a maior eficiência com doses de 84,35 $\mathrm{kg} \cdot \mathrm{ha}^{-1} \mathrm{e} 94,46 \mathrm{~kg} \mathrm{ha}^{-1}$ produzindo $696,76.76 \mathrm{~g}$ e 86,72.06g de MSPA e MSV respectivamente, uma altura média ideal de $94.15 \mathrm{~cm}$ com 123,98 kg.ha-1 e eficiência no uso de $\mathrm{P}(\mathrm{EU})$ de $13 \%$.

PALAVRAS CHAVE: Ecótono. fixation de P. GlycineMax. Intemperização.

\section{INTRODUCTION}

Among the three primary macronutrients $(\mathrm{N}$, $\mathrm{P}$ and $\mathrm{K})$, phosphorus $\left(\mathrm{P}_{2} \mathrm{O}_{5}\right)$ is the least extracted by plants and is usually the nutrient used in greater amounts as fertilizer. The risk of scarcity will increase in the coming decades due to limited world reserves and population growth estimates of nine billion, leading to an inevitable increase in demand for food, fiber and energy and therefore use of phosphate (CORDELL et al, 2009; ROY et al., 2016)

Most Brazilian soils present high retention/ fixation capacity of this macronutrient, as they are 
highly weathered and acidic, which favors the strong tendency of phosphorus $(P)$ applied to the soil to react through adsorption and precipitation reactions with $\mathrm{Al}$ (aluminum) $\mathrm{Fe}$ (iron) and $\mathrm{Ca}$ (calcium), forming lowsolubility compounds. Therefore, doses of phosphorus higher than those required by plants are often applied via fertilizers, especially in new cultivation areas (MARTIN and MARSCHNER, 2006; NOVAIS et al., 2007; WITHERS et al., 2018).

$P$ is an element that plays a fundamental role in all metabolites related to the acquisition and use of energy, being an important nutrient for legume nutrition, as well as for nodulation and fixation of atmospheric nitrogen. Thus, its deficiency is one of the main abiotic stresses that affect plants growth, especially in tropical soils (MALAVOLTA et al., 1989; OLDAY, 2006; NOVAIS et al., 2007). Stress caused by low $P$ availability in the soil leadsthe efficiency of nutrient utilization by plants to be different among species and among cultivars of the same species (MAHANTA et al., 2014; LYNCH, 2015; FAGERIA, 2016).

Estimates of scarcity combined with low $P$ soil availability, successive increases in phosphate fertilizer and food prices, and potential geopolitical stress indicate the need to improve phosphorus $(P)$ efficiency of the agricultural sector by developing strategies, together with good management practices, allowing plants to be more efficient in the absorption and utilization of nutrients. The objective was to evaluate the efficiency of phosphate fertilization in commercial soybean cultivarsof Brazilian cerrado soils, identifying the most efficient $P$ use cultivar (FUE) and if this cultivar is the most productive in terms of shoot dry matter (SDM), pod dry mass (PDM), number of pods (NP) and responsive regarding height parameter.

\section{MATERIAL AND METHODS}

The experiment was conducted under field conditions in an experimental area provided by EmpresaBrasileira de InfraestruturaAeroportuária (INFRAERO) located in the municipality of Imperatriz, Brazil ( $5^{\circ} 31^{\prime} 32$ 'S and $47^{\circ} 26^{\prime} 35^{\prime} \mathrm{W}$ ), with average altitude of 92 meters above sea level. The region climate is defined as Tropical Aw, according to the Köppen classification (PEEL et al., 2007), with annual average rainfall of $1476 \mathrm{~mm}$.

The experimental field soil was classified as Planosol(SANTOS, 2013). The soil chemical characteristics and granulometric fractions are shown in Table 1.

Table 1. Soil chemical analysis of the experimental area.

\begin{tabular}{|c|c|c|c|c|c|c|c|c|c|c|c|c|}
\hline $\mathrm{pH}$ & MO & $P$ & $\mathrm{~K}$ & $\mathrm{Ca}$ & $\mathrm{Mg}$ & $\mathrm{Al}$ & $\mathrm{H}+\mathrm{Al}$ & CTC & SB & V & $\mathrm{m}$ & $S$ \\
\hline $\mathrm{CaCl}_{2}$ & $\mathrm{~g} \cdot \mathrm{dm}^{-3}$ & $\mathrm{mg} \cdot \mathrm{dm}^{-3}$ & & $\mathrm{ol}_{c} \cdot \mathrm{dm}^{-3}$ & & & & & & $\%$ & & $m g \cdot d^{-3}$ \\
\hline 4.8 & 18.4 & 13.5 & 0.2 & 1.6 & 0.69 & 0.00 & 1.70 & 4,19 & 2,49 & 59,43 & 0 & 4.23 \\
\hline
\end{tabular}

Sand: $780 \mathrm{~g} \cdot \mathrm{kg}^{-1}$. silt: $110 \mathrm{~g} \cdot \mathrm{kg}^{-1}$. clay: $110 \mathrm{~g} \mathrm{~kg}^{-1}$.

The experimental design was randomized complete block design, with treatments arranged in a $2 \times 4$ factorial scheme, two soybean cultivars and four phosphorus levels, 0,60, 120 and $180 \mathrm{~kg} \mathrm{ha}^{-1}$, with four replicates, totaling 32 experimental units. Each unit had an area of $4 \mathrm{~m}^{2}$ and single superphosphate was used as $\mathrm{P}_{2} \mathrm{O}_{5}$ source.

Soybean cultivars used were BRS 333 RR and BRS 9180 IPRO, made available by the Empresa Brasileira de Pesquisa Agropecuária (Embrapa), unit of Imperatriz, MA, Brazil. BRS 333 cultivar of RR technology (Roundup Ready) has a determined growth rate and maturation cycle from 118 to 128 days, high resistance to lodging, excellent productive potential combined with wide adaptation, good plant branching and resistance to diseases like stem canker, frogeye leaf spot, bacterial pustule and soybean mosaic virus (smv). BRS 9180 cultivar, INTACTA RR2 PRO technology, with growth rate and flower coloring similar to the previous one, has purple coloring flower, average height of $78 \mathrm{~cm}$, maturation from 104 to 131 days, moderate resistance to lodging, rusticity, high capacity to withstand summer and excellent branching, and resistance to diseases such as stem canker (Diaporthephaseolorum f. sp. meridionalis), frogeye 
leaf spot (Cercosporasojina) and bacterial pustule (Xanthomonas axonopodis pv. glycines).

Soybean seeds were inoculated with peat-based inoculant containing Bradyrhizobium japonicum bacteria, nitrogen fixers to assist in the availability of this nutrient to plants, with dose of $200 \mathrm{~g}$ of inoculant and $300 \mathrm{ml}$ of additive for 50 $\mathrm{kg}$ of soybean seeds, according to manufacturer's recommendations.

Seeding was carried out in September 2016, in 4 rows per plot, with spacing of $0.4 \mathrm{~m}$ between rows and $8 \mathrm{~cm}$ between plants. The 2 central rows were used for sampling, while the 2 lateral rows were considered border.

At 20 days after emergence (DAE), some plants were sampled to verify the inoculation efficiency with nitrogen fixing bacteria, and it was observed that the incidence of nodules in the root system was very low. It was decided to provide $40 \mathrm{~kg} \mathrm{ha}^{-1}$ of nitrogen at 30 DAE through urea, incorporating it to the strip next to the planting row (Sediyama, 2015).

Weed management was carried out through application of $0.5 \mathrm{~L} \mathrm{ha}^{-1}$ of FUSILADE $250 \mathrm{EW}$, which is a class III systemic herbicide and active ingredient Butyl (R) - 2-(4-(5-trifluoromethyl-2-pyridyloxy)phenoxy)-propionate (FLUAZIFOP-P-BUTYL) Butyl (R) - 2-(4-(5-trifluoromethyl-2-pyridyloxy)-phenoxy)propionate (FLUAZIFOP-P-BUTYL).

High incidence of silverleaf whitefly (Bemisiaargentifolii) was observed, being controlled at 30 DAE with the use of CONNECT systemic insecticide of active ingredient BETA-CYFLUTHRIN and IMIDACLOPRID at concentration of $750 \mathrm{ml} \mathrm{L}$ in $100 \mathrm{~L}$ syrup ha-1, according to recommendations in the product registration for the crop. Twenty days after application, the same insecticide was used to control brown stink bug (Euschistosheros), at dose of $20 \mathrm{ml}$ to $10 \mathrm{~L}$.

At 40 and 55 DAE, 9180 I PRO and 333 RRcultivars, respectively, were present at R1 stage, at the beginning of flowering, at which time height was measured with the help of a measuring tape, sampling 10 plants located in the central rows of each plot.

BRS 9180 IPRO cultivar was harvested at 79 DAE and BRS 333 RR cultivar at 86 DAE for determination ofshoot dry mass (SDM) and pod dry mass (PDM). With the aid of pruning shears, five plants were removed from each experimental unit with cut of $5 \mathrm{~cm}$ above the soil surface and pods were separated from shoots. The plant material was packed in paper bags, duly identified and submittedto forced air circulation oven with temperature of $60^{\circ} \mathrm{C}$ until reaching constant weight.

Phosphate fertilizer use efficiency was evaluated by the following equation:

$$
\text { FUE }=\frac{\text { SDMf }- \text { SDMO }}{\text { Pf }}
$$

Where: FUE is the fertilizer use efficiency; SDMf is the shoot dry mass of plants that received phosphate fertilizer; SDM0 is the shoot dry mass of plants that did not receive phosphate fertilizer; Pf is the dose of phosphate fertilizer applied (FAGERIA, 1998).

Data were analyzed for normality by the ShapiroWilk test (SHAPIRO et al., 1968) and homoscedasticity by the Levene test (Levene, 1960) with no need for data transformation. Data obtained were submitted to regression analysis, adjusting equations based on phosphorus doses using the Sigmaplot statistical software version 13 . The interaction by the $5 \% \mathrm{~F}$ significant test and the magnitude of determination coefficientswas adopted as criterion in the choice of the model. Subsequently, data were submitted to analysis of variance at $5 \%$ error probability.

\section{RESULTS AND DISCUSSION}

Cultivars presented different behaviors in relation to P205doses for the evaluated variables. BRS 333 RR cultivar showed significant quadratic behavior that, in treatment with $93.78 \mathrm{~kg}^{-\mathrm{ha}^{-1}}$ P205,obtained higher physical yield in biomass production with696.73g MSPA (Figure 1). Treatment with no phosphate fertilization obtained average SDM higher than treatment with $180 \mathrm{~kg} \mathrm{ha}^{-1}$. This behavior evidences the lack of need of phosphate fertilization for this soybean cultivar under similar fertility conditions. When evaluating SDM of BRS 9180 IPRO cultivar (Figure 1), significant linear decrease was observed as phosphate fertilizer doses increased. In control treatment, adjusted SDM was $532.65 \mathrm{~g}$, while under high $\mathrm{P}_{2} \mathrm{O}_{5}\left(180 \mathrm{~kg} \cdot \mathrm{ha}^{-1}\right)$, minimum SDM result of $383.31 \mathrm{~g}$ was obtained. 
Figure 1. Average shoot dry mass values of BRS 333 RR and BRS 9180 IPRO cultivars ( $p \leq 0.05)$.

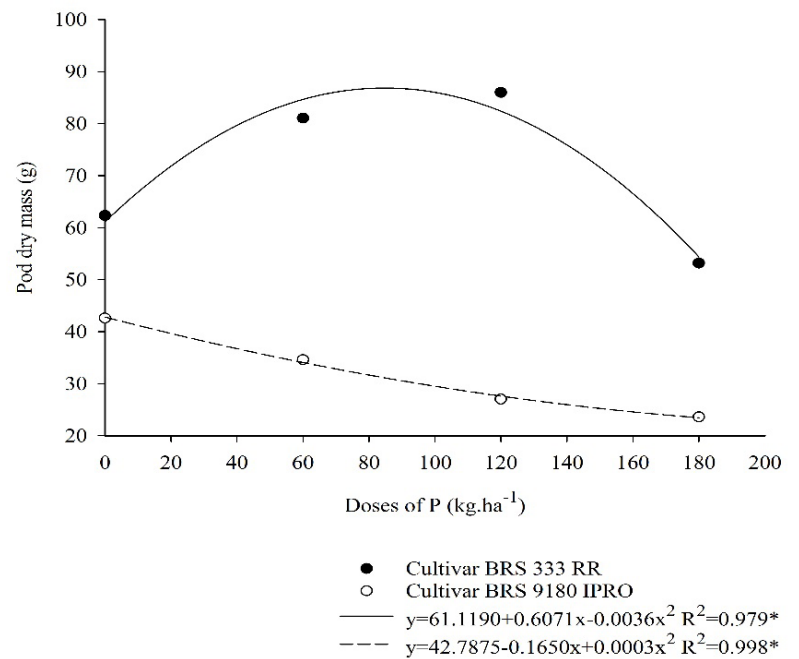

In figure 2, dose of $84.347 \mathrm{~kg} \cdot \mathrm{ha}^{-1}$ had maximum efficiency with $86.72 \mathrm{~g}$ of PDM in BRS 333 RR cultivar, while BRS 9180 IPRO cultivar once again behaves linearly and negatively with doses of $\mathrm{P}_{2} \mathrm{O}_{5}$, reaching $22.91 \mathrm{~g}$ under conditions of $180 \mathrm{~kg}$. ha- ${ }^{-1}$.This adjustment, although not significant for the effect of $\mathrm{P}_{2} \mathrm{O}_{5}$ dose factor, was negative to the linear model, indicating that probably this cultivar has relative efficiency for biomass production under conditions of average $\mathrm{P}_{2} \mathrm{O}_{5}$ levels in soils with adequate $\mathrm{N}$ and $\mathrm{K}$ supply and water availability.

Figure 2. Average pod dry mass values of BRS $333 \mathrm{RR}$ and BRS 9180 IPRO cultivars $(p \leq 0.05)$.

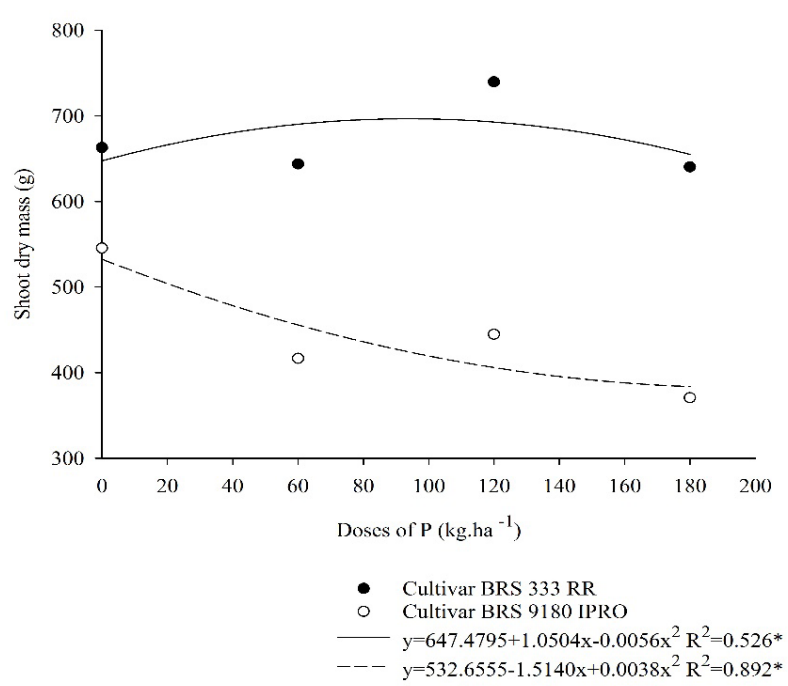

BRS 333 RR cultivar again behaves according to a quadratic curve, where the highest average height for the cultivar was under conditions of $120 \mathrm{~kg} \mathrm{ha}^{-1} \mathrm{P} 205$, with $94.15 \mathrm{~cm}$ (Figure 3). These results corroborate those of Rosa et al. (2015) who, in an INTACTA technology soybean test using P2O5doses 50, 100, 150 and $200 \mathrm{~kg} \mathrm{ha}^{-1}$ in the clayey dystrophic yellow red Latosol of Brazilian Cerrado, in Mato Grosso - MT, Brazil, verified that the different phosphorus doses influenced the height of plants, where the highest values were obtained with the highest applied dose.

Figure 3. Average plant height values of BRS 333 RR and BRS 9180 IPRO cultivars $(p \leq 0.05)$.



Cavalcante et al. (2010) evaluated BR 5033 cultivar under controlled conditions using Yellow Latosol soil and $\mathrm{P}_{2} \mathrm{O}_{5}$ doses of $0,50,100$ and 150 $\mathrm{kg} \cdot \mathrm{ha}^{-1}$ and recorded quadratic adjustment with the application of doses, obtaining maximum plant height of $108 \mathrm{~cm}$ with $\mathrm{P}_{2} \mathrm{O}_{5}$ dose of $137.5 \mathrm{~kg} \mathrm{ha}^{-1}$ and higher shoot dry mass with the application of $120 \mathrm{~kg} \mathrm{ha}^{-1}$. The authors pointed out that at doses higher than those mentioned above, no increase in height and SDM values was observed.

For height variable, BRS 9180 IPRO showed non-significant increasing effect as a function of $P$ doses (Figure 3 ). Control treatment presented the lowest adjusted height, which was $71.91 \mathrm{~cm}$, close to the average value described for 
the cultivar, which is $78 \mathrm{~cm}$ (NORTE et al. 2016), confirming the cultivar genotype characteristics under medium soil fertility and adequate water availability conditions. The highest mean height was obtained in treatment with $180 \mathrm{~kg}^{-h^{-1}} \mathrm{P}_{2} \mathrm{O}_{5}$ reaching $106.55 \mathrm{~cm}$.Mundstock andThomas (2005) reported that excess water in years of intense rainfall is reflected in excessive vegetative growth. This factor, together with adequate $\mathrm{P}, \mathrm{N}$ and $\mathrm{K}$ availability may have contributed to the excessive vegetative development of this cultivar, which average height is $78 \mathrm{~cm}$ (Vilela et al., 2016).

Dry mass productivity is associated with nutrient accumulation by plants. Mauad et al. (2010) reported that soybean plants with excessive growth and large leaves reduce radiation distribution inside the crop due to shading, reducing the photosynthetic activity and consequently formation of pods. This fact may explain the decreased average valuesof BRS 9180 IPRO cultivar as a function of $\mathrm{P}_{2} \mathrm{O}_{5}$ doses. The provision of adequate, and mainly balanced, amounts of essential elements is more important to achieve high yields than the provision of larger amounts of these nutrients alone (Primavesi, 1985). This fact may explain the lower SDM and PDM production at dose of $180 \mathrm{~kg} \mathrm{ha}^{-1}$.

Single superphosphate has high solubility in water and is readily available to plants. Considering that soil presents low buffer capacity for $P$ and sandy texture (Table 1), high $\mathrm{P}_{2} \mathrm{O}_{5}$ doses $(120$ and $180 \mathrm{~kg}$ $\mathrm{ha}^{-1}$ ) did not reflect economic returns for BRS 9180 IPRO cultivar in this experiment, since high doses of this fertilizer may have promoted an antagonistic interaction with $\mathrm{Zn}$, since there are reports in literature that point to the antagonistic effect between $P$ and $Z n$. Parker et al. (1992) reported that under high doses of phosphate fertilizers, reduction in dry matter yield was observed in two tomato cultivars for a certain $\mathrm{Zn}$ level in soil.

Variables production and productivity were not evaluated in this project, considering that there was no grain harvest; however, data on the number of pods were obtained, where BRS 333 RR cultivar obtained the highest average with 1182.75 pods, under conditions of $60 \mathrm{~kg} \mathrm{~h}^{-1}$, and even results were not statistically significant, cultivar under dose of 120 $\mathrm{kg} \mathrm{ha}^{-1}$ produced average number of pods of 947.50 (Figure 4), which reinforces the results of other works such as the Zucareli et al. (2011) and Silva et al. (2015), who reported the same economic efficiency with dose $120 \mathrm{~kg} \mathrm{~h}^{-1}$, in quadratic response for the yield of 'Carioca' beans and soybean respectively, and in soils with low phosphorus availability. Colombo et al., (2016) presented average of 69 pods per soybean plant in high $\mathrm{P}_{2} \mathrm{O}_{5}$ environment with 120 $\mathrm{kg} \mathrm{ha}^{-1}$, which represented an increase of $56.8 \%$ in relation to plants under conditions of low $\mathrm{P}_{2} \mathrm{O}_{5}(40 \mathrm{~kg}$ ha $^{-1}$ ) with 44 pods per plant.

Figure 4. Average number of pods of BRS $333 \mathrm{RR}$ and BRS 9180 IPRO cultivars ( $p \leq 0.05)$.

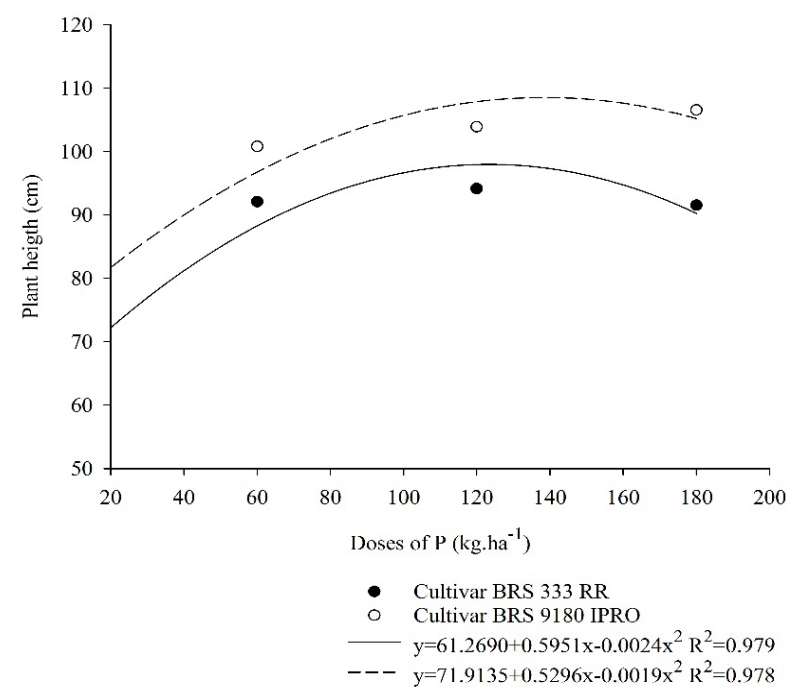

Fertilizer doses considered economical correspond to more than $80 \%$ of the dose responsible for maximum production, which may represent the economic viability of the use of phosphate fertilizer in soybean cultivation. According to de Sousa \& Lobato (2003), the economic efficiency for phosphate fertilizer is between $80 \%$ and $95 \%$ of maximum grain yield.

FUE of BRS 333 RR cultivar was similar between P205doses of 60 and $120 \mathrm{~kg} \mathrm{ha}^{-1}$, which reached $12 \%$ and $13 \%$ of phosphate fertilizer use efficiency for each dose, respectively (Table 2). Dose of $180 \mathrm{~kg} \mathrm{ha}^{-1}$, in addition to presenting the lowest average PDM, also presented the lowest FUE of $P$ fertilizer applied, $3 \%$. 
Table 2. Phosphate fertilizer use efficiency (FUE) by the evaluated soybean cultivar.

\begin{tabular}{|l|l|}
\hline Doses of $\mathbf{P}\left(\mathbf{k g}^{-\mathbf{h}} \mathbf{}^{-1}\right)$ & BRS 333 RR \\
\hline & FUE \\
\hline 60 & $\%$ \\
120 & 12 \\
180 & 13 \\
\hline
\end{tabular}

FUE calculations were performed using average SDM values of each dose.

The supply of suitable doses of readily soluble phosphate fertilizers such as single superphosphate or triple superphosphate from the beginning of soybean crop development is essential for the formation of the essential reproductive parts and for the good formation of pods and grains, increasing crop production (Taiz and Zeiger, 2017).

Therefore, during the growth and development of soybean plants in experimental field, single superphosphatedose of $123.98 \mathrm{~kg} \cdot \mathrm{ha}^{-1}$, together with nutrients added to the soil ( $\mathrm{K}$ and $\mathrm{N}$ ), met the nutritional balance of this cultivar, considering that there was efficiency variation in the different parameters tested, with doses ranging from $62.99 \mathrm{~kg} \cdot \mathrm{ha}^{-1}$ for number of pods to $123.98 \mathrm{~kg}$ ha $^{-1}$ for plant height.

In this context, the probability of occurrence of response of BRS 333 RR soybean cultivar in relation to phosphate fertilization in soils with medium $P$ availability and sandy texture will be lower when $P$ supply is higher than $123.98 \mathrm{~kg}$ ha $^{-1}$, reducing plant height, SDM, DPM and number of pods, respectively. BRS 333 RR cultivar can showed reduction about $65.51 \%$ per hectare under the consumption of phosphate fertilizer in the Brazilian cerrado.Thus, after further field trials to confirm the hypotheses tested, the cultivar could be presented as responsive and $\mathrm{P}_{2} \mathrm{O}_{5}$ use efficient.BRS 333 RR cultivar exhibits satisfactory behavior in terms of soil fertility by decreasing the consumption of inputs, whileBRS 9180 IPRO cultivar obtained negative response to high $\mathrm{P}_{2} \mathrm{O}_{5}$ doses, differing from reports in literature regarding culture and mineral.

\section{REFERENCES}

Cavalcante, I.F.; Costa Filho, J.F.; Oliveira, J.C.; Pereira, W.E.; Oliveira, F.A.; Silva, I.F. Crescimento do milhoadubado com nitrogênio e fósforoem um LatossoloAmarelo. RevistaBrasileira de CiênciasAgrárias - Brazilian Journal of Agricultural Sciences, 2010, 4, 3, 238-244.

Colombo, G. A.; Machado Filho, G. C.; Pelúzio, J. M.; Pires, L. P. M.; Daronch, D. J.Phosphorus use efficiency of soybean cultivars in cerrado conditions of Tocantins, Brazil. Journal of Bioenergy and Food Science, 2016.

Cordell, D.; Drangert, J. O.; White, S. The story of phosphorus: Global food security and food for thought. Global Environmental Change,2009, 292-305.

De Sousa, D. M. G.; Lobato, E. Adubação fosfatada em solos da região do Cerrado. Peachtree Corners, 2003.

Fageria, N. K. Otimização da eficiência nutricional na produção das culturas. Revista Brasileira de Engenharia Agrícola e Ambiental, 1998, 6-16.

Taiz,E.L.; Zeiger, I. M.; Møller, A. M. Fisiologia e Desenvolvimento Vegetal. In International Journal of Food Science \& Technology (6th ed.), 2017.

Levene, $\mathrm{H}$. Robust tests for equality of variances. In I. Olkin, H. Hotelling, \& et al. (Eds.), Contributions to Probability and Statistics: Essays in Honor of Harold Hotelling, 1960, (pp. 278-292). California: Stanford University Press.

Lynch, J. P.Root phenes that reduce the metabolic costs of soil exploration: Opportunities for 21st century agriculture. Plant, Cell and Environment,2015, September,vol. 38.

Mahanta, D.; Rai, R. K.; Mishra, S. D.; Raja, A.; Purakayastha, T. J.; Varghese, E. Influence of phosphorus and biofertilizers on soybean and wheat root growth and properties. Field Crops Research,2014, 166, 1-9.

Malavolta, E.; Vitti, G.; Sebastiao, A. Avaliacao do estado nutricional das plantas: principios e aplicacoes.1989, 319.

Martin, M. H.; Marschner, H. The Mineral Nutrition of Higher Plants. The Journal of Ecology, 2006, 76(4), 1250. 
Mauad, M.; Silva, T. L. B.; Neto, A. I. A.; Abreu, V. G. Influência da densidade de semeadura sobre características agronômicas na cultura da soja. Agrarian, 2010, 3(9, Dourados), 175-181.

Mundstock, C. M.; Thomas, A. L.Soja: Fatores que afetam o crescimento e o rendimento de grãos. Porto Alegre: Departamento de Plantas de Lavoura da Universidade Federal do Rio Grande do Sul, 2005. Evangraf.

Norte, E. M.; Lambert, E. S.; Kiihl, R. A. D. S.; Almeida, L. A. De,Soja.Roraima, E. Cultivares de Soja para as Regiões Norte e Nordeste do Brasil, 2016, 40.56.

Novais, R. F.; Alvarez V.; V. H., Barros, N. F. de.; Fontes, R. L. F.; Cantarutti, R. B.; NEVES, J. C. L. (Ed. ).Fertilidade do solo. (1st ed.). Viçosa: Sociedada Brasileira de Ciência do Solo, 2007.

Novais, R.F,; Alvarez V.; V. H., Barros, N. F. De.; Fontes, R. L. F.; Cantarutti, R. B.; Neves, J. C. L.Fertilidade do solo. In Matéria orgânica do solo. Lavras: UFLA/ FAEPE, 2007.

Olday, F. C. Mineral Nutrition of Plants Mineral Nutrition of Plants: Principles and Perspectives Emanuel Epstein. BioScience, 2006, 22(12).

Oliveira, F. A., Cavalcante, L. F., Silva, I. F., Pereira, W. E., Oliveira, J. C., \& Costa Filho, J. F. Crescimento do milho adubado com nitrogênio e fósforo em um Latossolo Amarelo. Revista Brasileira de Ciências Agrárias - Brazilian Journal of Agricultural Sciences, 2009, 238-244.
Parker, D. R., Aguilera, J. J., \& Thomason, D. N. Zincphosphorus interactions in two cultivars of tomato (Lycopersicon esculentum L.) grown in chelatorbuffered nutrient solutions. Plant and Soil,1992, 143

Peel, M. C., Finlayson, B. L., \& McMahon, T. A. (2007). Updated world map of the Köppen-Geiger climate classification. Hydrology and Earth System Sciences, 11(5), 1633-1644. https://doi.org/10.5194/hess-111633-2007

Primavesi, A. O manejo ecológico do solo : a agricultura em regiões tropicais (8th ed.). São Paulo: Nobel, 1985.

Rosa, M. P.; Pittelkow, F. K.; Pasqualli, R. M. (2015). Doses e métodos de aplicação de fósforo na cultura da soja (p. 9). p. 9. Lucas do Rio Verde: Fundação Rio Verde.

Roy, E. D.; Richards, P. D.; Martinelli, L. A.; Coletta, L.; Della, Lins, S. R. M., Vazquez, F. F.; Porder, S. The phosphorus cost of agricultural intensification in the tropics. Nature Plants, 2016, 16043.

Santos, H. G. dos. Sistema brasileiro de classificação de solos (3rd ed.). Brasília: Embrapa, 2013.

Shapiro, S. S., Wilk, M. B., \& Chen, H. J.. A Comparative Study of Various Tests for Normality. Journal of the American Statistical Association, 1968, 63(324)

Silva, A. de A.; Couto Junior, P. A.; de Almeida, L. F. V.; Lana, R. M. Q. Teores de nutrientes foliares em função de arranjos de plantio de soja submetida a doses e formas de aplicação de fósforo, 2015, p. 4. Natal.

Zucareli, C., Prando, A. M., Júnior, E. U. R., \& Nakagawa, J. Revista Ciência agronômica. Revista Ciência Agronômica,2011, 32-38. 